\title{
Paleo American finds from Venezuela: evidence to discuss the spread of Fell Points and the peopling of Northern South America
}

Keywords: Fishtail points; human peopling; South America.

Palavras-chave: pontas "Rabo de peixe"; povoamento humano; América do Sul.

\begin{abstract}
Fishtail" or just "Fell” points represent an excellent marker to know and discuss the existence of colonizers hunter-gatherers living in Central and South America during the end of the Pleistocene at about $11000-10000{ }^{14} \mathrm{C} \mathrm{yr}$ BP. Investigations of Venezuelan fishtail points yielded additional data on their manufacturing procedure to help discuss the human colonization of northern South America. The finds from northern Venezuela on the Caribbean Sea yielded a link arguing for the use of the Atlantic slope and the current continental shelf during human dispersal in South America.
\end{abstract}

Resumo: "Rabo de peixe" ou somente pontas Fell representam um excelente indicador para conhecer e discutir a existência de colonizadores caçadores-coletores que viveram na América Central e do Sul durante o final do Pleistoceno há aproximadamente 11.000-10.000 14C anos AP. Pesquisas com pontas Rabo de peixe da Venezuela proporcionaram dados adicionais sobre o seu processo de fabricação contribuindo na discussão da colonização humana do norte da América do Sul. As descobertas do norte da Venezuela no Mar do Caribe defendem a utilização da vertente Atlântica e da plataforma continental atual durante a dispersão humana na América do Sul.

Recebido em 22 de fevereiro de 2016. Aprovado em 23 de julho de 2016.
"Fishtail", alternatively called "Fell's Cave" or just "Fell" points represent an excellent lithic marker to know the existence of colonizing hunter-gatherers living in Central and South America during the end of the Pleistocene at about $11000-10000{ }^{14} \mathrm{C}$ yr BP ( 11-10 KYBP). These points share several attributes with some North Paleo American specimens and constitute a striking archaeological phenomenon that must be investigated in detail. To better understand the diverse aspects of "fishtail" point technology as well as the colonization process of South America, I have been conducting a long-term research program to study Paleo American lithic assemblages in both Hemispheres of the New World from technological, experimental and comparative archaeological perspectives (NAMI, 1997, 2010a, 2010b, 2014a, among others). Following the investigations devoted to know the distribution and technology regarding raw material selection, reduction sequence and function on South American Fell points, this paper reports further data on specimens recovered in northern Venezuela, northern coast of northern South America. 

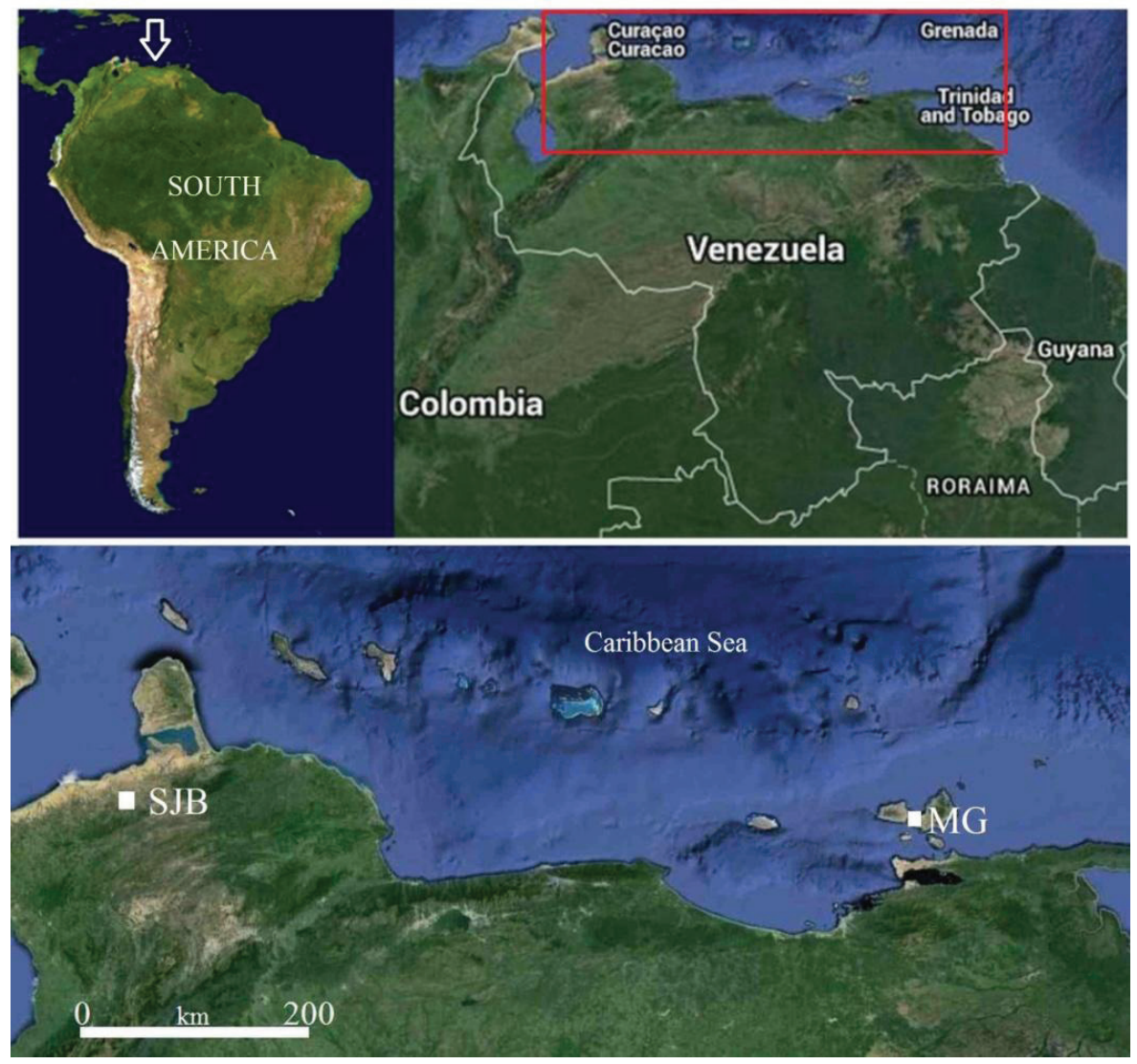

Figure 1 - Map of South America and the location of San José de Bruzual (SJB), and María Guevara (MG) locales in northern Venezuela, denoted with a rectangle (after Google Maps, 2015).

\section{Archaeological data: observations and results}

The studied artifacts belong to the collection formerly assembled by Mr. Carlos Césari. A part of it is currently curated in the Museo Etnográfico de la Universidad de Buenos Aires, Argentine Republic. Among diverse lithic objects there is a sample ( $\mathrm{n}=$ 4) of "fishtail" specimens that has been found on the surface of open-air localities. They come from María Guevara (MG), and San José de Bruzual (SJB); situated in Nueva Esparta and Falcon states, northeastern and northwestern part of the country on the Caribbean Sea coast (Figure 1).

SJB $\left(11^{\circ} 08^{\prime} \mathrm{N} 70^{\circ} 33^{\prime} \mathrm{W}\right)$ is located near the El Jobo locality, famous for the lanceolate points that bear its name (CRUXENT; ROUSE, 1958, p. 68-ss.). MG is situated at the natural monument Las tetas de María Guevara $\left(10^{\circ} 57^{\prime} 28^{\prime \prime} \mathrm{N} 64^{\circ} 07^{\prime} 01^{\prime \prime} \mathrm{W}\right)$, which are twin hills near Restinga Lagoon in central Margarita Island (MI). Table 1 depicts relevant morphological and technological attributes of the specimens reported in this paper.

Table 1. Salient morphological and technological attributes of the artifacts reported in this paper. Note: All the measurements are given in mm. L: Length, W: Width, T: Thickness, (): indicates fractured piece

\begin{tabular}{ccccccccccc}
\hline Piece \# & $\begin{array}{c}\text { Site/ } \\
\text { Locality }\end{array}$ & Artifact & Condition & Material & L & W & T & $\begin{array}{c}\text { Stem } \\
\text { length }\end{array}$ & $\begin{array}{c}\text { Stem } \\
\text { width }\end{array}$ & Fig. \\
\hline 1 & SJB & Preform & Fractured & Quartzite & $(31.2)$ & 30.0 & 8.3 & & & $2 \mathrm{a}$ \\
2 & MG & $\begin{array}{c}\text { Finished } \\
\text { product }\end{array}$ & “ & Milky quartz & $(41.1)$ & $(30.3)$ & 8.0 & 23 & 21 & $2 \mathrm{~b}$ \\
3 & " & Preform & “ & “ & $(38.0)$ & 41.0 & 9.2 & - & - & $2 \mathrm{c}$ \\
4 & “ & Preform & “ & “ & $(24.5)$ & 35.5 & 7.0 & - & - & $2 \mathrm{~d}$ \\
\hline
\end{tabular}


Figure $2 \mathrm{~A}$ represents the basal portion of a preform broken by a reverse hinge produced during fluting. It is made of a fine grain brownishgray quartzite commonly used in the region for manufacturing early tools (CRUXENT; ROUSE, 1958; BRYAN et al., 1978; NAMI, 1993-94). Abrasion is noted on the edge of the convex base. The artifacts from MG correspond to two fractured preforms, and a broken Fell point made on milky quartz. The blade of the latter shows three fractures with flat surfaces; two of them with angles of $\sim 90^{\circ}$, and the third of $\sim 40^{\circ}$ (Figure $2 \mathrm{~B}$ ). They may have probably been produced by impact. As seen in several pieces of the collection, these kinds of breaks are originated in natural fissures visible with a 10X magnification glass. One of them is clearly observed on the left side of the failed flute performed in the preform exhibited in Figure 2C. Two flutes of 39 and $20 \mathrm{~mm}$ long are located on both faces of the stem, showing that the edges were abraded; a usual feature of fishtail specimens. An almost finished "typical" Fell point is exhibited in figure 2D. It was broken during the first fluting, probably made by direct percussion with an organic soft flaking implement. For fluting, the striking platform was prepared by beveling the edge with retouches of $\sim 2-4 \mathrm{~mm}$ wide and a $65^{\circ}$ angle (Figure 2E). This preparation is similar to other ones observed in specimens from El Inga and Tolonta sites in Ecuador (NAMI, 2014a: Figure 10); in Quebrada Santa María (CHAUCHAT et al., 1998a: Figure 53 right), Quisqui Puncu (LYNCH, 1970, Figures 12j, 20d-e) in Peru; and Paso del Puerto, Cerros Azules and Yi river in Uruguay (NAMI, 2001, 2013: Figure 4o, 2015: Figure 7a). As a flaking raw material, quartz has different qualities and fracture properties than other rocks (JONES, 2010). Artifacts from MG suggest that this material has low to medium flaking quality with fissures that impeded satisfactory chipping. Nevertheless, it allows the removal of flutes as well the use of pressure flaking. Interestingly, despite its variable flaking qualities, different forms of vein and crystal quartz have been used for manufacturing Fell points (BRICEÑO; ROSARIO, 1999; CAPELETTI, 2011; JACKSON et al., 2007; LOPONTE et al., 2015; NAMI, 2009; NUÑEZ et al., 1994; among others). Fishtails from MG are strongly similar to "typical" specimens found in Central and South America (NAMI, 2014b: Figure 18).

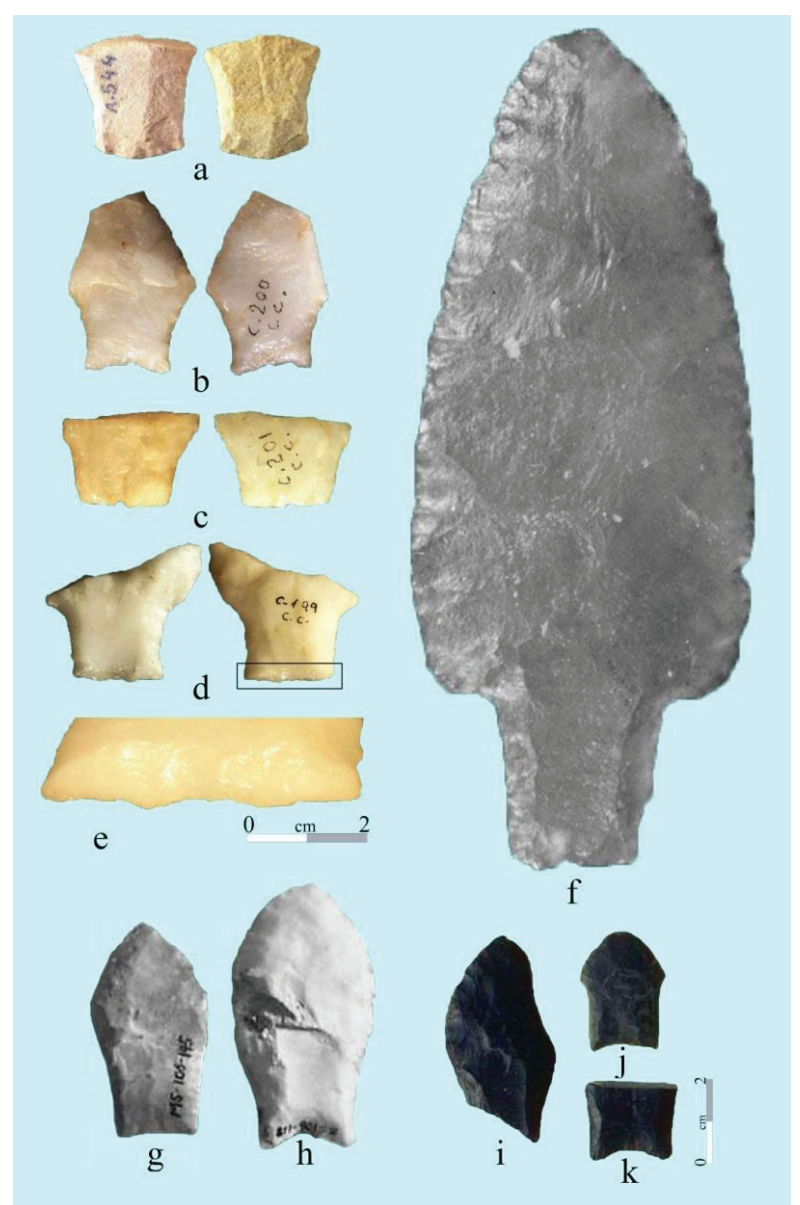

Figure 2 - a) Preform from San José de Bruzual, b-d) specimens from María Guevara, e) close-up of platform preparation denoted with a rectangle on the preform illustrated in d), f) Fell point from the Cuyuni river, g) Pedregal, h) Siraba, i) Los Planes de Giosne, j-k) La Hundición a-e) photos by the author, f) by courtesy of B. Meggers, and h-l) A. Jaimes.

\section{Discussion and conclusion}

Diverse kinds of Paleo American points are present in Venezuela. For many years, most of the attention was paid to El Jobo specimens (CRUXENT; ROUSE, 1958; BRYAN, 1983; DILLEHAY et al., 1992; DILLEHAY, 2000; JAIMES, 1999). However, there are Clovis-like (PEARSON; REAM, 2005) or, "Clovisoid" points (SZABADICS ROKA 2010); also, exemplars (JAIMES, 1999: Figure 7) compatible with Suwannee and Simpson from Southeastern USA (DUNBAR; HEMMING, 2004; DUNBAR, 2012). Due to the basal constriction that produced a "fish-tailed effect" (WORMINGTON, 1957, p. 83; MORROW; MORROW, 2002), despite its differences I generically call them here as "eastern North American fish-tailed points" (ENAFP). Additionally, 
Fell specimens have also been reported in Venezuela (JAIMES, 1999; SZABADICS ROKA, 2010). They were found in several locales, among them Cueva del Tigre, San Simón Aragua de Maturín, Monagas; Kilómetro 95 carretera ciudad Guayana a Upata, Bolívar; Caimancito, Falcón, and; Manicuare Sucre (CÉSARI pers. comm. 2015). Exemplars illustrated in figure 2G-K come from Pedregal, Sibara (Paraguana Peninsula), Los Planes de Giosne and La Hundición sites, respectively located in Falcón, and Sanare states (JAIMES, 1999). Specimens displayed in Figure $2 \mathrm{H}-\mathrm{I}$ and $\mathrm{K}$ are fluted, and the ones showed in Figure $2 \mathrm{G}$ and J were highly resharpened; finally, there is a broken stem (Figure $2 \mathrm{~K}$ ). The latter and the fluted pieces are similar to the lanceolate points from Central and South America. For instance from San Rafael, Guatemala; Madden Lake, Panama; and El Inga, Ecuador (BELL, 1965: Figure 10c; BIRD; COOKE, 1978: Figure 1a-d; NAMI, 2014b: Figure 22a-d). Crossing the Venezuelan border, an exceptional exemplar comes from the Cuyuni River, Mazani district, Guiana (Figure 2F). Formerly reported by Evans and Meggers (1960), it was recently identified as a Fell point (NAMI, 2010a, 2014b). Like many large fishtails, it was mostly reduced by bifacial thinning and finished by regularizing the edges with short pressure retouches (NAMI, 2011; LOPONTE et al., 2015). The stem shows a flute surpassing the blade/stem junction. Near the southern Venezuelan border, Meggers (2007: Figure 4.9 \#11) illustrates a large fishtail fluted point from the Upper Negro river, in north Brazil. It is comparable with other large Brazilian specimens (LOPONTE et al., 2016).

The presence of Fell points in this area is significant, because it fills gaps in their geographical dissemination and allows us to address issues on the human colonization of South America. Certainly, for a long time, its western part -mainly the Andean Cordillera- has been proposed as the dispersion area of Paleoamerican hunter-gatherers that used them (e.g. MAYER-OAKES, 1963; SCHOBINGER, 1987). However, adding to the specimens previously reported in the Atlantic slope, its distribution in the eastern part of South America has been recently growing (FLEGENHEIMER et al., 2013; LOPONTE et al., 2015, 2016; NAMI, 2013, 2015a). Hence, due to the abovementioned finds, the Caribbean Sea, and northern part of South America are crucial areas to understand the human dispersal and the possible relations between Paleo North and South American foragers. They are relevant to discuss the continuity existing between ENAFP to South America (FAUGHT, 2006; NAMI, 2013, 2015a; PEARSON, 2002, 2004, 2016). Similarly to the isthmus of Central America, the Venezuelan finds call the attention on the role of the Caribbean region in the peopling of South America. In this scenario, not only southeastern North America and the isthmus acquire relevancy but also the Atlantic continental shelf and the island chains in the Caribbean Sea between the Gulf of Mexico and Northern South America. Actually, throughout the last glacial maximum (LGM) the sea dropped more than $100 \mathrm{~m}$ below present level (CLARK; MIX, 2000; LAMBECK; CHAPPELL, 2001; LAMBECK et al., 2014). This phenomenon exposed previously drowned continental shelves and formed vast coastal plains and land-bridges around the world. During, and following the LGM, these areas were affected by some of the most striking environmental climate change on the planet. Supporting diverse range of fauna, flora, and humans, extensive portions went from productive coastal plains and land bridges to rapidly submerged shelves within the span of a few human lifetimes (HETHERINGTON et al., 2003). During the Late Pleistocene, at the time of the peopling of the New World, different parts of the Earth witnessed important low sea levels until the early Holocene (LAMBECK et al., 2014; PARLAGRECO; SILENZI, 2010). Particularly, during the last 20 KYBP the Gulf of Mexico and Caribbean Sea experienced significant fluctuations until the initial Holocene (DUNBAR, 2012; FAUGHT, 20022004; JACKSON, 2013). In the Peri-Caribbean belt of Northern South America, based on paleontological and geomorphological evidence, Ochsenius (1979a, $1979 b, 1980)$ suggested the existence of various biogeographical bridges between the continental border and nearby islands in northern Venezuela. Particularly at 11-10 KYBP, in some parts the sea level was $\sim-20-25 \mathrm{~m}$ below than today (JACKSON, 2013: Figure 2.13). These facts are significant, because 
as a component of the Peri-Caribbean belt, MI is currently located $\sim 40 \mathrm{~km}$ from the continent. Hence, during Paleo-American time, it was probably part of the exposed continental shelf joined to the mainland by a land-bridge, which might be another one crossed by Fell points makers during the colonization of South America (NAMI, 2001b). Hence, it is possible to consider that during periods of lowered sea level in the Atlantic Ocean, the exposed areas located along the Gulf of Mexico and Caribbean Sea have linked southeastern North America with Central and Northern South America. Then, the finds from MG are probable evidence of this phenomenon, witnessing that the exposed Atlantic shelflying along the east coast of the New World, was important habitation and migration corridors for the colonizer journey of early peoples that characterize one of the colonization events from North to South America.

Acknowledgements: I am indebted to: C. Césari and Ana I. de Bellard for their kindness, continuous data input and information; M. Tarragó director of Museo Etnográfico for allowing the study the collection; G. Ammirati for her cooperation during my work at the museum; B. Meggers (R.I.P), A. Jaimes for kindly providing me the photographs illustrated in figure $2 \mathrm{f}$ and g-k respectively, and G. A. Pearson for his help and cooperation during the edition of this paper

\section{References}

BELL, R. E. Investigaciones arqueológicas en el sitio de El Inga, Ecuador. Quito: Casa de Cultura Ecuatoriana, 1965.

BIRD, J.; COOKE, R. The Occurrence in Panama of two types of Paleoindian projectile points. In: BRYAN, A. L. (Ed.). Early Man in America from a Circum Pacific Perspective. Edmonton: Occasional Papers 1, Department of Anthropology, University of Alberta, 1978. p. 263-272.

BRICEÑO ROSARIO, J. G. Quebrada Santa María: Las puntas cola de pescado y la antigüedad del hombre en Sudamérica. Boletín de Arqueología PUCP, 3, 19-39, 1999.
BRYAN, A. South America. In: SHUTLER, Jr. R. (Ed.). Early Man in the New World. Beverly Hills: Sage Publications, 1983. p. 137-148.

.; CASAMIQUELA, R. M.; CRUXENT, J. M.; GRUHN, R.; OCHSENIUS, C. An El Jobo Mastodon Kill at Taima-taima, Venezuela. Science, 200, 12751277, 1978.[DOI:10.1126/science.200.4347.1275]

CAPELETTI, L. E. Primer hallazgo de una punta de proyectil "Cola de Pescado" en la provincia de Entre Ríos. Libro de resúmenes del VI Congreso de Arqueología de la Región Pampeana, Revista del Museo de La Plata. Arqueología, 12, 86, 66R-67R, 2011.

CHAUCHAT, C., GÁlVEZ, C.; BRICEÑO, J.; S. UCEDA, S. Sitios arqueológicos de la zona de Cupisnique y margen derecha del valle de Chicama, Patrimonio Arqueológico Zona Norte/4. Travaux de L'Institut Français d'Etudes Andines 113. TrujilloLima: Instituto Nacional de Cultura La Libertad and Instituto Francés de Estudios Andinos, 1998.

CLARK, P. U.; MIX, A. C. Ice Sheets by Volume. Nature, 406, p. 689-690, 2000.

CRUXENT, J. M.; ROUSE, I. An archeological chronology of Venezuela. Washington D.C.: Pan American Union, 1958.

DILLEHAY, T.; ARDILA CALDERÓN, G.; POLITIS, G.; BELTRAO, M. DA C. Earliest hunter and gatherers of South America. Journal of World Prehistory, n.6, p. 145-204, 1992.

The Settlement of the Americas: A New

Prehistory. New York: Basic Books, 2000.

DUNBAR, J. S. The Search for Paleoindian Contexts in Florida and the Adjacent Southeast. 2012. $347 \mathrm{f}$. Thesis (Doctorate in Philosophy) - The Florida State University, Tallahassee, 2012.

.; HEMMINGS, C. A. Florida Paleoindian Points and Knives. In: BONNICHSEN, R.; LEPPER, B. (Eds.). New Perspectives on the First Americans. 
College Station: Texas A\&M University Press, 2004. p. $65-72$.

EVANS, C.; MEGGERS, B. J. Archeological Investigations in British Guiana, Bureau of American Ethnology Bulletin 177. Washington D.C.: Smithsonian Institution, 1960.

FAUGHT, M. K. Submerged Paleoindian and Archaic Sites of the Big Bend, Florida. Journal of Field Archaeology, 29, p. 273-290, 2002-2004.

The Underwater Archaeology of Paleolandscapes, Apalachee Bay, Florida. American Antiquity, 69, p. 275-289, 2004.

Paleoindian Archaeology in Florida and Panama. In: MORROW, J. E.; GNECCO, C. (Eds.). Paleoindian Archaeology. A Hemispheric Perspective. Gainesville: University Press of Florida, 2006. p. 164-183.

FLEGENHEIMER N.; MIOTTI L.; MAZZIA, N. Rethinking early objects and landscapes in the Southern Cone: Fishtail-Point concentrations in the Pampas and Northern Patagonia. In: GRAF, K. E.; KETRON, C. V.; WATERS, M. R. (Eds.). Paleoamerican Odissey. College Station: Center for the Study of the First Americans, 2013. p. 359-376.

HETHERINGTON, R.; BARRIE, J. V.; REID, R. G. B.; MACLEOD, R.; SMITH, D. J.; JAMES, T. S.; KUNG, R. Late Pleistocene coastal paleogeography of the Queen Charlotte Islands, British Columbia, Canada, and its implications for terrestrial biogeography and early postglacial human occupation. Canadian Journal of Earth Sciences, 40, p.1755-1766, 2003.

JAIMES, A. Nuevas evidencias de cazadores recolectores y aproximación al entendimiento del uso del espacio geográfico en el Noroccidente de Venezuela. Sus implicaciones en el contexto suramericano. Arqueología del Área Intermedia, 1, p.83-120, 1999.

JACKSON, D.; MÉNDEZ, C.; SEGUEL, R.; MALDONADO. A.; VARGAS, G. Initial occupation of the Pacific coast of Chile during late Pleistocene times. Current Anthropology, 48, p. 725-731, 2007. doi:10.1086/520965

JACKSON, L. P. Caribbean Sea Level Change: Observational Analysis from Millennial to Decadal Timescales. 2013, 197 f. (Doctorate in Philosophy) - The University of Leeds School of Earth and Environment, Leads, 2013.

JONES, S. Quartz tool technology in the Northeast Georgia Piedmont. In:Nami, H. G. (Ed.). Experiments and Interpretation of Traditional Technologies: Essays in Honor of Errett Callahan. Buenos Aires: Ediciones de Arqueología Contemporánea, 2010. p. 431-510.

LAMBECK, K.; CHAPPELL, J. Sea level change through the last glacial cycle. Science, 292, p. 679686, 2001.

; ROUBY, H.; PURCELL, A.; SUN, Y.; SAMBRIDGE, M. Sea level and global ice volumes from the Last Glacial Maximum to the Holocene. Proceedings of the National Academy of Sciences of the United States of America. doi:10.1073/ pnas.1411762111, 2014.

LOPONTE, D.; CARBONERA, M.; SILVESTRE, R. Fishtail Projectile Points from South America: The Brazilian Record. Archaeological Discovery, 3, p. 85-103, 2015. doi:10.4236/ad.2015.33009.

; OKUMURA, M.; CARBONERA, M. New records of fishtail projectile points from Brazil and its implications for its peopling. Journal of Lithic Studies, 3(1), 2016. doi:10.2218/jls.v3i1.1312.

LYNCH, T. F. Excavations at Quishqui Puncu in the Callejon de Huaylas, Peru. Pocatello: Occasional Papers of the Idaho State University Museum, 26, 1970.

MAYER-OAKES, W. J. Early Man in the Andes. Scientific American, 208, p.117-128, 1963.

MEGGERS, B. Mid-Holocene climate and cultural dynamics in Brazil and the Guianas. Climate Change and Cultural Dynamics. In: ANDERSON, D.; 
MAASCH, G.; KIRK A.; SANDWEISS, D. H. (Eds.). A Global Perspective on Mid-Holocene Transitions. Amsterdam: Elsevier Inc. 2007. p. 117-155.

MORROW, J.; MORROW, T. The Clovis-GaineyFolsom continuum: Technological and morphological variation in midwestern fluted points. In: CLARK, J. E.; COLLINS, M. B. (Eds.). Folsom Technology and Lifeways. Lithic Technology Special Publication 4, Tulsa: University of Oklahoma, 2002. p. 141-157.

NAMI, H. G. Aportes para el conocimiento de técnicas líticas del Pleistoceno Final. Análisis de artefactos bifaciales del Norte de Venezuela (Colección Edmonton, Canada). Relaciones de la Sociedad Argentina de Antropología, XIX, p. 417435, 1993/1994.

Investigaciones actualísticas para discutir aspectos técnicos de los cazadores-recolectores del tardiglacial: El problema Clovis-Cueva Fell. Anales del Instituto de la Patagonia, 25, p.152-186, 1997.

Paleoindian archaeological evidence and two cases of land bridges in southern South America. In: YIM, W.W. S.; CHIVAS, A. R. (Eds.). Continental Shelves during the Last Glacial Cycle. Hong Kong SAR: Department of Earth Sciences, University of Hong Kong, 2001. p. 43-45.

. Crystal Quartz and Fishtail Projectile Points: Considerations on Raw Materials Selection by Paleo-Southamericans. Current Research in the Pleistocene, 26, p. 9-12, 2009.

- Tecnología Paleoindia de Sudamérica: Nuevos experimentos y observaciones para conocer la secuencia de reducción Fell. Origenes 9. Montevideo: Fundación Arqueología Uruguaya, 2010a.

Experiments to understand North and South American Late Pleistocene Lithic Reduction Sequences: An Actualistic and Comparative Study. In: NAMI, H. G. (Ed.). Experiments and Interpretation of Traditional Technologies: Essays in Honor of Errett Callahan. Buenos Aires: Ediciones de Arqueología Contemporánea, 2010b. p. 203-253.
Exceptional Fell projectile points from Uruguay: More data on Paleoindian technology in the southern cone. Current Research in the Pleistocene, 28, p.112-116, 2011.

.Archaeology, Paleoindian research and lithic technology in the middle Negro River, central Uruguay. Archaeological Discovery, 1, p.1-22, 2013.

Secuencias de Reducción Bifaciales Paleoindias y Puntas Fell en el Valle del Ilaló (Ecuador): Observaciones para comprender la tecnologia lítica pleistocénica en Sudamérica. In: Farias M.; Lourdeau A. (Eds.). Peuplement et modalités d'occupation de l'Amérique du sud: l'apport de la technologie lithique. Prigonrieux: @ rchéo-éditions.com and Impr. Copy-média, 2014a. p. $179-220$.

Arqueología del último milenio del Pleistoceno en el Cono Sur de Sudamérica, puntas de proyectil y observaciones sobre tecnología Paleoindia en el Nuevo Mundo. In: Farias M.; Lourdeau A. (Eds.). Peuplement et modalités d'occupation de l'Amérique du sud: l'apport de la technologie lithique. Prigonrieux: @rchéo-éditions.com and Impr. Copy-média, 2014b. p. 279-336.

New Records and Observations on PaleoAmerican Artifacts from Cerro Largo, Northeastern Uruguay and a Peculiar Case of Reclaimed Fishtail Points. Archaeological Discovery, 3, p.114-127. 2015a. doi:10.4236/ad.2015.33011.

Paleoamerican Artifacts from Cerro Largo, Northeastern Uruguay. PaleoAmerica, 1, p. 288-292, 2015b.

NUÑEZ, L.; CASAMIQUELA, R.; SCHIAPPACASSE, V.; NIEMEYER, H.; VILLAGRÁN, C. Cuenca de Taguatagua en Chile: El ambiente del pleistoceno y ocupaciones humanas. Revista Chilena de Historia Natural, 67, p.503-519, 1994.

OCHSENIUS, C. Ancient beaches and biogeographic landbridges resulting from Pleistocene Neotectonism and Glacioeustatism. In: OCHSENIUS, C. (Ed.). Quaternary Ecology in the Peri-Caribbean 
Arid Belt, Corian Region, Northernmost South America. Scientific Monographs 2, CIPICS Program, Coro: Francisco de Miranda University. 1979a. p. $94-107$.

The Peri-Caribbean Arid belt context during the Late Pleistocene. In: OCHSENIUS, C.; GRUHN, R. (Eds.). Taima Taima. A Late Pleistocene Paleo-Indian Kill Site in Northernmost South America - Final Report of 1976 Excavation. Saabrücken: CIPICS/South American Quaternary Documentation Program. 1979b. p. 35-39.

Cuaternario en Venezuela. Introducción a la Paleoecología en el norte de Suramérica. Cuadernos Falconianos, 3, p. 1-68, 1980.

PARLAGRECO, L.; SILENZI, S. Adapting to Climate Change in Time. Projections on Relative Sea-level Rise over the Next Century. Project act, ISPRA Institute for Environmental Protection and Research. 2010. Available in: http://www.actlife.eu/medias/40projections-of-relative-sea-level-rise-over-the-nextcentury.pdf. Accessed: July 12 $2^{\text {th }}, 2014$.

PEARSON, G. A. Pan-Continental Paleoindian Expansions and Interactions as Viewed from The Earliest Lithic Industries of Lower Central America. 2002, 654 f. (Doctorate in Philosophy) Department of Anthropology, University of Kansas, Lawrence, 2002.

Pan-American Paleoindian Dispersals and the Origins of Fishtail Projectile Points as
Seen through the Lithic Raw-Material Reduction Strategies and Tool-Manufacturing Techniques at the Guardiría Site, Turrialba Valley, Costa Rica. In: BARTON, C. M.; CLARK, G. A.; YESNER, D. R.; PEARSON, G. A. (Eds.). The Settlement of the American Continents. Tucson: The University of Arizona Press, 2004. p. 85-102.

Bridging the gap: Interpreting the technocultural relations of Fluted Point assemblages in Middle America. Enviado para su publicación a: Mucho más que un puente terrestre. MS, 2016. .; REAM, J. Clovis on the Caribbean Coast of Venezuela. Current Research in the Pleistocene, 22, p. 28-30, 2005.

SCHOBINGER, J. La Patagonia en el marco de las más antigua prehistoria americana. Comunicaciones. Primeras jornadas de arqueología de la Patagonia. Rawson: Dirección de Cultura de la Provincia, 1987. p. 279-293.

SZABADICS ROKA, M. Cazadores especializados Clovis en Paraguaná, estado de Falcón Venezuela. 2010. Available at: http://miklosszabadics.blogspot. com/2010/12/cazadores-espeos-clovisoides-en.htm, Accessed: October $24^{\text {th }}, 2012$.

WORMington, H. M. Ancient Man in North America. Denver: Denver Museum of Natural History, 1957. 